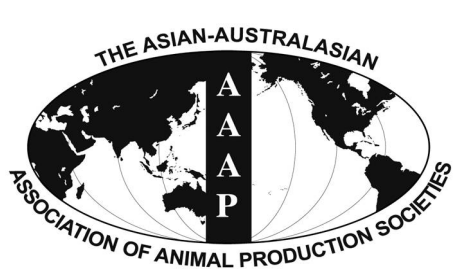

Open Access

Asian Australas. J. Anim. Sci.

Vol. 29, No. 1 : 119-125 January 2016

http://dx.doi.org/10.5713/ajas.15.0180

www.ajas.info

pISSN 1011-2367 elSSN 1976-5517

\title{
Effect of Fat Level and the Ripening Time on Quality Traits of Fermented Sausages
}

\author{
Dong-Gyun Yim, Kyoung-Hwan Jang ${ }^{1}$, and Ku-Young Chung ${ }^{1}{ }^{*}$ \\ Department of Health Administration and Food Hygiene, Jinju Health College, Jinju 660-757, Korea
}

\begin{abstract}
The objective of this study was to investigate the effect of the fat reduction on the physicochemical and microbiological characteristics of fermented sausages during ripening and drying. Low fat fermented sausages were produced with different fat levels $(30 \%, 20 \%, 10 \%$, and $5 \%)$ under ripening conditions and fermented process. Samples from each treatment were taken for physicochemical and microbiological analyses on the $0,1,2,3,4,5,7,10,14$, and 21 st day of ripening. In proximate analysis, the fat reduction in sausages produced an increase in moisture, protein and ash contents during ripening and drying $(\mathrm{p}<0.05)$. The weight losses were significantly higher in high fat formulations during the first 4 days, whereas those were higher in low fat ones after 10 days of storage $(\mathrm{p}<0.05)$. Fat reduction was responsible for an increase in shear force values after 3 days of storage. The volatile basic nitrogen $(\mathrm{VBN})$ value of the low fat samples was significantly higher $(\mathrm{p}<0.05)$. Low fat sausages reduced the extent of lipid oxidation. The lower fat level produced redder sausages. Total plate bacteria and Pseudomonas counts of sausages showed no significant differences. Production of low fat sausages resulted in the physicochemical and microbiological attributes equal to or better than the high fat sausages without negative effects, except only a higher VBN and weight loss. (Key Words: Fat Level, Fermented Sausages, Physicochemical Trait)
\end{abstract}

\section{INTRODUCTION}

Fat contributes to nutritional (source of essential fatty acids, liposoluble vitamins, and energy), organoleptic (flavour, texture, and mouthfeel), and technological properties (release of moisture) in meat products (Olivares et al., 2010). Nevertheless, fat in meat and meat products is considered a triggering factor in the development of some chronic diseases (World Health Organization, 2003). For this reason, health organizations all over the world have promoted lowering the intake of total dietary fat intake to less than $30 \%$ of total calories, particularly saturated fatty acids and cholesterol, as a mean of preventing cardiovascular heart disease (Nutrition Committee, American Heart Association, 1986; Kris-Etherton et al., 1988). Thus, meat researchers have focused on developing

\footnotetext{
* Corresponding Author: Ku-Young Chung. Tel: +82-33-7300534, E-mail: kychung@sangji.ac.kr

${ }^{1}$ Department of Animal Science and Biotechnology, Sangji University, Wonju 220-702, Korea.

Submitted Mar. 3, 2015; Revised May 27, 2015; Accepted Jun. 2, 2015
}

new formulations by reducing fat levels.

Fermented sausages are meat products with a high fat content. Traditional sausages made with a normal recipe have fat contents around $32 \%$ directly after manufacture, but during the first week these values rise to about $40 \%$, as a result of drying, and after 4 weeks to about $40 \%$ to $50 \%$ (Wirth, 1988). Therefore, it is valuable to reduce the amount of pork backfat used in fermented sausages, since it contains a high content of saturated fat. However, low-fat fermented sausages become not only harder, but have high weight loss and an unacceptable appearance due to intensely wrinkled surfaces (Muguerza et al., 2002). Consequently, fat reduction can affect the sensory characteristics of the products (Giese, 1996; Mendoza et al., 2001) and increase the toughness of meat products (Barbut and Mittal, 1996). Furthermore, the granulated fat in fermented sausages helps to loosen the sausage mixture and this aids the continuous release of moisture from the inner layers of the product; a process absolutely necessary for undisturbed fermentation and flavour/aroma development (Muguerza et al., 2002). For these reasons, fermented 
sausages are the most difficult of meat products as far as fat reduction is concerned (Wirth, 1988). Generally, fat reduction $(10 \%)$ affected the external appearance and flavour intensity of fermented sausages (Liaros et al., 2009) while higher reduction percentages $(20 \%)$ produced a suitable acceptability (Papadima and Bloukas, 1999; Olivares et al., 2010). Very few studies have dealt with fat reduction of fermented sausages during ripening and drying. The objective of this study was to investigate the effect of the fat reduction on the physicochemical and microbiological characteristics of fermented sausages during ripening and drying.

\section{MATERIALS AND METHODS}

\section{Fermented sausages manufacture}

For fermented sausages production, fresh beef, refrigerated pork, and frozen pork backfat were obtained in a vacuum packaged condition from a local meat packer. Pork and beef meat were trimmed of visible fat and pork backfat of adhering skin. Both meats and pork backfat were cut and weighed in appropriate amounts, vacuum packed and kept frozen at $-24^{\circ} \mathrm{C}$ for 3 days. Four treatments of fermented sausages were prepared at different levels $(30 \%$, $20 \%, 10 \%$, and $5 \%$ ) of pork backfat. Fermented sausages were made with ground beef, pork, pork backfat, curing sodium chloride $(2.8 \%)$, garlic $(0.05 \%)$, mettwurst additive $(0.1 \%)$, monosodium glutamate $(0.05 \%)$, glucose $(0.5 \%)$, and starter culture $(0.4 \%)$. A commercially available frozen meat starter culture (Lyocarni RBL-73, Lyocarni, SACCO, Milan, Italy) consisting of Lactobacillus curvatus and Staphylococcus xylosus with $2.5 \times 10^{6} \log$ colony-forming unit $(\mathrm{CFU}) / \mathrm{g}$ was added at a concentration of $6 \log \mathrm{CFU} / \mathrm{g}$, according to the manufacturer's instructions. Beef, pork, and backfat were cut in a bowl chopper (Fujee Co., Seoul, Korea) at low speed to the desired particle size, about 3 to 5 $\mathrm{mm}$ and mixed in a mixer (Fujee Co., Korea). Starter culture and ingredients were added during mixing. All treatments, about $10 \mathrm{~kg}$ each, were replicated three times in separate meat sources of each replicate. The mixture was then stuffed using a stuffer (H20E, TALSA Co., Northampton, EU) into $25 \mathrm{~mm}$ diameter hog casings (Seoul, Korea). The casings had been pre-soaked in lukewarm water. Sausage filling was restrained and tied with a string by hand. Special cleaning and sanitizing measures were taken during sausage manufacture in a pilot plant. All equipment was rinsed thoroughly between treatments. Samples were dried and ripened in a laboratory smoke chamber (BTDS76P, Bradley, Galesburg, IL, USA). The following conditions of relative humidity (RH) and temperature were applied: day 0 until day 3, 93\% $\mathrm{RH}$ and $20^{\circ} \mathrm{C} \pm 1^{\circ} \mathrm{C}$; day $3,81 \%$ to $85 \% \mathrm{RH}$ and $17^{\circ} \mathrm{C} \pm 1{ }^{\circ} \mathrm{C}$; day 4 until day $7,88 \%$ to $90 \% \mathrm{RH}$ and $18^{\circ} \mathrm{C} \pm 2^{\circ} \mathrm{C}$; day 7 until day
$10,87 \% \mathrm{RH}$ and $16^{\circ} \mathrm{C}$; after day $10,60 \%$ to $70 \% \mathrm{RH}$ and $16^{\circ} \mathrm{C}$. The sausages were smoked after 3 and 7 days in the chamber. Samples from each treatment were taken for physicochemical and microbiological analyses on the $0,1,2$, $3,4,5,7,10,14$, and 21 st day of ripening. All the results in proximate composition were expressed as the mean of triplicate trial at each sampling time.

\section{Proximate composition and physicochemical analyses}

Before analysis, the fat was manually removed from the sausages slices by a knife. All determinations were carried out on the homogenized sample, in triplicate. Moisture, fat, protein and ash were determined on samples using with a slightly modified method of AOAC (Horwitz, 2000). The $\mathrm{pH}$ of samples was determined with a $\mathrm{pH}$ meter (PHM201, Radiometer, Villeurbanne, France). The $\mathrm{pH}$ values of samples were measured by blending a $10 \mathrm{~g}$ sample with 90 $\mathrm{mL}$ distilled water for 60 seconds in a homogenizer (Ultraturrax, T25-S1, IKA, Staufen, Germany). For measurement of weight loss, two strings of sausages from each treatment were weighed just before the sausages were put into the fermentation room. The same strings were reweighed on the $0,1,2,3,4,5,7,10,14$, and 21 st day of ripening. Weight loss was expressed as a percentage of the initial weight. The mean of the two measurements was recorded. Color measurements were taken with a Minolta chromameter (Model CR-410, Minolta Co. Ltd., Tokyo, Japan). Commission Internationale de l'Eclairage $\mathrm{L}^{*}, \mathrm{a}^{*}$, and $\mathrm{b}^{*}$ values were determined with measurements standardized with respect to a white calibration plate $\left(\mathrm{L}^{*}=94.4, \mathrm{a}^{*}=\right.$ $\left.0.313, b^{*}=0.319\right)$ after 30 minutes blooming at room temperature. Color measurements for each of three replicates, always trying to avoid areas with excess fat, were taken and the value was recorded. The TBARS of samples were analyzed by the modification method described by the procedure of Witte (Witte et al., 1970). Readings were made on a spectrophotometer (X-MA 3000, Human Ltd., Seoul, Korea) at $530 \mathrm{~nm}$. A micro-diffusion method described by Conway (1950) was modified for the determination of volatile basic nitrogen (VBN) in sausage samples. Each sample ( $3 \mathrm{~g}$ ) was homogenized (Ultra-turrax, T25-S1) for 30 seconds with $27 \mathrm{~mL}$ of distilled water. The supernatant solution was filtered using a filter paper (No. 4, Whatman). A $0.01 \mathrm{~N}$ of boric acid was placed in the inner section of a Conway micro-diffusion cell (Sibata Ltd., Tokyo, Japan). A $1 \mathrm{~mL}$ sample solution and $1 \mathrm{~mL}$ of saturated $\mathrm{K}_{2} \mathrm{CO}_{3}$ were also placed into the outer section of the same cell, and the lid was immediately closed. The cell was incubated at $25^{\circ} \mathrm{C}$ for 60 minutes, and it was then titrated against $0.02 \mathrm{~N} \mathrm{H}_{2} \mathrm{SO}_{4}$. The VBN value was reported as $\mathrm{mg} / \%$. Shear force values were analyzed by the method described by the procedure of Bourne (1978). The samples were prepared a cubic form $(30 \times 30 \times 20 \mathrm{~mm})$ and were cut 
perpendicular to the longitudinal orientation of the muscle fiber with a Warner-Bratzler shear attachment on a texture analyzer (TA-XT2, Stable Micro System Ltd., Godalming, $\mathrm{UK})$. The maximum shear force value $(\mathrm{kg})$ was recorded for each sample. Test and post-test speeds were set at $1.0 \mathrm{~mm} / \mathrm{s}$.

\section{Microbiological analysis}

Ten grams of samples from each treatment was also weighed and then homogenized with $90 \mathrm{~mL}$ distilled water using a stomacher (STOMACHER 400 CIRCULATOR, Seward Ltd., Worthing, UK) for 90 seconds at room temperature. Total aerobic plate counts (TACs) were analyzed according to the Standards for Processing and Ingredients Specifications of Livestock Products, Animal, Plant and Fisheries Quarantine and Inspection Agency Notification (Quarantine and Inspection Agency, 2014). Homogenized microbial extracts were serially diluted with distilled water by 10 -fold. Portions of the samples $(0.1 \mathrm{~mL})$ were plated separately on each plate and spread thoroughly. TACs were enumerated on plate count agar (Difco, Difco Laboratories, Detroit, MI, USA) and colonies were counted after incubation at $35^{\circ} \mathrm{C} \pm 1^{\circ} \mathrm{C}$ for 48 hours. Pseudomonas spp. were assessed by spread technique on Pseudomonas Agar (Difco, USA), incubation at $30^{\circ} \mathrm{C} \pm 1^{\circ} \mathrm{C}$ for 48 hours. All analyses were performed in duplicate, and results expressed as logarithm colony-forming units per gram of samples $(\log \mathrm{CFU} / \mathrm{g})$.

\section{Statistical methods}

Experimental design used was 4 (fat level) $\times 10$ (ripening time) factorial analysis. An analysis of variance were performed on all the variables measured using the General Linear Model procedure of the SAS statistical package (SAS, 2002). The Duncan's multiple range test $(p<0.05)$ was used to determine differences among the treatment means.

\section{RESULTS AND DISCUSSION}

\section{Proximate composition, physicochemical characteristics, and microbial analysis}

Effect of fat level for pork backfat on proximate composition of fermented sausages is shown in Table 1. The differences between the fat level on proximate composition were significant $(\mathrm{p}<0.05)$. The moisture, protein and ash contents were inversely proportional to the fat content during ripening and drying. The lower the added fat level, the higher moisture, protein and ash contents and the lower fat content were as expected. A similar finding was reported by Muguerza et al. (2002) and Olivares et al. (2010), who found that fat reduced sausages were lower in fat content and higher in moisture, protein and ash contents. The moisture content ranged from $51.48 \%$ to $63.91 \%$ at day 0 and from $17.69 \%$ to $25.03 \%$ on the 21 st day. At day 0 , the moisture content was the highest $(p<0.05)$ in fat reduced samples (T3). At the end of the ripening and drying process (day 21), the sausages reached a fat content of $47.27 \%$, $34.82 \%, 25.71 \%$, and $22.49 \%$ for the $30 \%, 20 \%, 10 \%$, and $5 \%$ formulations, respectively. Protein contents were $29.78 \%, 33.29 \%, 41 \%$, and $43.42 \%$ for the $30 \%, 20 \%, 10 \%$, and $5 \%$ formulations, respectively at day 21 . The storage conditions had significant effect on the proximate composition of the sausages $(p<0.05)$. During ripening and drying, the moisture contents of sausages were significantly decreased, while the fat, protein and ash content was increased on the $21 \mathrm{st}$ day compared to day $0(\mathrm{p}<0.05)$. A similar trend has been reported by Olivares et al. (2010), who found the reduction in moisture during ripening caused the increase in fat and protein contents.

Effect of fat level for pork backfat on physicochemical

Table 1. Effect of fat level for pork backfat on proximate composition of fermented sausages

\begin{tabular}{|c|c|c|c|c|}
\hline Treatment & Moisture (\%) & Fat $(\%)$ & Protein $(\%)$ & Ash (\%) \\
\hline \multicolumn{5}{|l|}{0 day } \\
\hline $\mathrm{C}^{1}$ & $51.48 \pm 0.37^{\mathrm{d}}$ & $32.29 \pm 0.21^{\mathrm{a}}$ & $12.82 \pm 0.38^{\mathrm{c}}$ & $3.31 \pm 0.08^{\mathrm{b}}$ \\
\hline $\mathrm{T} 1$ & $56.93 \pm 0.50^{\mathrm{c}}$ & $22.82 \pm 0.95^{\mathrm{b}}$ & $17.02 \pm 0.44^{\mathrm{b}}$ & $3.60 \pm 0.10^{\mathrm{ab}}$ \\
\hline $\mathrm{T} 2$ & $62.73 \pm 0.35^{\mathrm{b}}$ & $13.57 \pm 0.16^{\mathrm{c}}$ & $20.04 \pm 0.61^{\mathrm{a}}$ & $3.66 \pm 0.12^{\mathrm{a}}$ \\
\hline $\mathrm{T} 3$ & $63.91 \pm 0.73^{\mathrm{a}}$ & $13.87 \pm 0.54^{\mathrm{c}}$ & $19.14 \pm 0.74^{\mathrm{a}}$ & $3.84 \pm 0.26^{\mathrm{a}}$ \\
\hline \multicolumn{5}{|l|}{21 day } \\
\hline $\mathrm{C}$ & $17.69 \pm 0.09^{c}$ & $47.27 \pm 0.15^{\mathrm{a}}$ & $29.78 \pm 0.14^{\mathrm{d}}$ & $5.42 \pm 0.29^{d}$ \\
\hline $\mathrm{T} 1$ & $25.00 \pm 0.75^{\mathrm{a}}$ & $34.82 \pm 0.61^{\mathrm{b}}$ & $33.29 \pm 0.14^{\mathrm{c}}$ & $6.28 \pm 0.21^{\mathrm{c}}$ \\
\hline $\mathrm{T} 2$ & $25.03 \pm 0.26^{\mathrm{a}}$ & $25.71 \pm 0.73^{\mathrm{c}}$ & $41.00 \pm 0.85^{\mathrm{b}}$ & $7.68 \pm 0.25^{\mathrm{b}}$ \\
\hline T3 & $23.24 \pm 0.72^{\mathrm{b}}$ & $22.49 \pm 0.79^{\mathrm{d}}$ & $43.42 \pm 0.74^{\mathrm{a}}$ & $9.41 \pm 0.07^{\mathrm{a}}$ \\
\hline \multicolumn{5}{|c|}{ Average ripening time } \\
\hline 0 day & $58.76 \pm 0.49^{\mathrm{a}}$ & $20.64 \pm 0.47^{b}$ & $17.26 \pm 0.54^{b}$ & $3.60 \pm 0.14^{b}$ \\
\hline 21 day & $22.74 \pm 0.39^{\mathrm{b}}$ & $32.57 \pm 0.28^{\mathrm{a}}$ & $36.87 \pm 0.50^{\mathrm{a}}$ & $7.20 \pm 0.22^{\mathrm{a}}$ \\
\hline
\end{tabular}

Values are presented as means \pm standard deviation of three replicate experiments with three samples analyzed per replicate $(\mathrm{n}=9)$.

${ }^{1}$ C, $30 \%$ fat; T1, 20\% fat; T2, 10\% fat; T3, 5\% fat.

${ }^{\mathrm{a}-\mathrm{d}}$ Figures with different letters within a same column differ significantly $(\mathrm{p}<0.05)$. 
characteristics of fermented sausages is shown in Table 2. Weight losses were significantly affected by the fat level $(p<0.05)$. During ripening and drying, the weight losses of sausages were significantly increased on the $21 \mathrm{st}$ day compared to day $0(\mathrm{p}<0.05)$. This agrees with the results of Liaros et al. (2009), who found the weight loss of high and low-fat non-packaged sausages continuously increased during ripening. While the weight losses of fermented sausages were higher in $30 \%$ and $20 \%$ formulations than in $10 \%$ and $5 \%$ during the first 4 days, they were lower in $30 \%$ and $20 \%$ after 10 days of storage. This is in agreement with the results of other studies (Papadima and Bloukas, 1999; Liaros et al., 2009), which have indicated low-fat sausages had higher weight loss than high-fat ones at the end of ripening. Weight losses depend on various factors including the temperature and $\mathrm{RH}$ of the ripening room, the air movement and the ripening time, and the width of the casings, the material of which the casings are made and the fat content of the sausages (Muguerza et al., 2002). The initial $\mathrm{pH}$ of fermented sausages ranged from 5.28 to 5.36 and the final $\mathrm{pH}$ on the 21 th day from 4.62 to 4.92 . No differences in $\mathrm{pH}$ value were found between the high-fat $(30 \%)$ and low-fat $(5 \%)$ treatments during ripening and drying. Similar results have been reported by Bloukas et al. (1997) and Muguerza et al. (2002). Papadima and Bloukas (1999) mentioned the higher weight loss of sausages stored in the ripening room may also be attributed to their lower $\mathrm{pH}$ values. During ripening and drying, the $\mathrm{pH}$ of sausages were significantly decreased on the 21 st day compared to day $0(\mathrm{p}<0.05)$.

During ripening and drying, the shear force values of sausages were increased on the 21 st day compared to day 0 $(p<0.05)$. The shear force values of fermented sausages were higher in $5 \%$ fat formulations than in other treatments after 3 days of storage $(p<0.05)$. Previous studies have shown that sausage texture in low fat sausages caused an increase in chewiness and hardness at longer ripening times (Mendoza et al., 2001; Olivares et al., 2010). Total VBN concentration was used as an index of meat freshness, because it is increased by the levels of microbial

Table 2. Effect of fat level for pork backfat on physicochemical traits of fermented sausages

\begin{tabular}{|c|c|c|c|c|c|c|c|c|c|c|}
\hline \multirow{2}{*}{ Variable } & \multicolumn{10}{|c|}{ Days of ripening } \\
\hline & 0 & 1 & 2 & 3 & 4 & 5 & 7 & 10 & 14 & 21 \\
\hline \multicolumn{11}{|c|}{ Weight loss (\%) } \\
\hline $\mathrm{C}^{1}$ & & $3.23^{\mathrm{aF}}$ & $4.21^{\mathrm{aF}}$ & $8.74^{\mathrm{aE}}$ & $13.52^{\mathrm{aD}}$ & $21.63^{\mathrm{C}}$ & $28.91^{\mathrm{B}}$ & $39.04^{\mathrm{bA}}$ & $45.33^{\mathrm{bA}}$ & $47.34^{\mathrm{bA}}$ \\
\hline $\mathrm{T} 1$ & & $3.14^{\mathrm{aF}}$ & $4.12^{\mathrm{aF}}$ & $8.90^{\mathrm{aE}}$ & $14.09^{\mathrm{aD}}$ & $23.14^{\mathrm{C}}$ & $29.99^{\mathrm{B}}$ & $41.81^{\mathrm{bA}}$ & $48.36^{\mathrm{bA}}$ & $50.32^{\mathrm{bA}}$ \\
\hline $\mathrm{T} 2$ & & $3.17^{\mathrm{aF}}$ & $4.21^{\mathrm{aF}}$ & $9.16^{\mathrm{aE}}$ & $14.79^{\mathrm{aD}}$ & $24.53^{\mathrm{C}}$ & $30.47^{\mathrm{B}}$ & $45.56^{\mathrm{aA}}$ & $54.09^{\mathrm{aA}}$ & $55.94^{\mathrm{aA}}$ \\
\hline $\mathrm{T} 3$ & & $2.69^{\mathrm{bF}}$ & $3.06^{\mathrm{bF}}$ & $7.65^{\mathrm{bE}}$ & $12.52^{\mathrm{bD}}$ & $21.66^{\mathrm{C}}$ & $28.29^{\mathrm{B}}$ & $47.24^{\mathrm{aA}}$ & $53.68^{\mathrm{aA}}$ & $55.64^{\mathrm{aA}}$ \\
\hline \multicolumn{11}{|l|}{$\mathrm{pH}$} \\
\hline $\mathrm{C}$ & $5.35^{\mathrm{A}}$ & $5.42^{\mathrm{A}}$ & $4.61^{\mathrm{B}}$ & $4.38^{\mathrm{B}}$ & $4.54^{\mathrm{B}}$ & $4.50^{\mathrm{B}}$ & $4.67^{\mathrm{B}}$ & $4.52^{\mathrm{B}}$ & $4.61^{\mathrm{B}}$ & $4.64^{\mathrm{B}}$ \\
\hline $\mathrm{T} 1$ & $5.36^{\mathrm{A}}$ & $5.45^{\mathrm{A}}$ & $4.69^{\mathrm{B}}$ & $4.46^{\mathrm{B}}$ & $4.55^{\mathrm{B}}$ & $4.52^{\mathrm{B}}$ & $4.64^{\mathrm{B}}$ & $4.63^{\mathrm{B}}$ & $4.71^{\mathrm{B}}$ & $4.82^{\mathrm{B}}$ \\
\hline $\mathrm{T} 2$ & $5.34^{\mathrm{A}}$ & $5.38^{\mathrm{A}}$ & $4.63^{\mathrm{B}}$ & $4.49^{\mathrm{B}}$ & $4.64^{\mathrm{B}}$ & $4.65^{\mathrm{B}}$ & $4.74^{\mathrm{B}}$ & $4.94^{\mathrm{B}}$ & $4.93^{\mathrm{B}}$ & $4.92^{\mathrm{B}}$ \\
\hline $\mathrm{T} 3$ & $5.28^{\mathrm{A}}$ & $5.38^{\mathrm{A}}$ & $4.76^{\mathrm{B}}$ & $4.35^{\mathrm{B}}$ & $4.43^{\mathrm{B}}$ & $4.38^{\mathrm{B}}$ & $4.46^{\mathrm{B}}$ & $4.53^{\mathrm{B}}$ & $4.60^{\mathrm{B}}$ & $4.62^{\mathrm{B}}$ \\
\hline \multicolumn{11}{|c|}{ Shear force $(\mathrm{kg})$} \\
\hline $\mathrm{C}$ & $0.19^{\mathrm{C}}$ & $0.18^{\mathrm{C}}$ & $0.71^{\mathrm{C}}$ & $1.34^{\mathrm{bC}}$ & $1.43^{\mathrm{bC}}$ & $1.43^{\mathrm{bC}}$ & $1.72^{\mathrm{bC}}$ & $2.20^{\mathrm{bB}}$ & $3.50^{\mathrm{cA}}$ & $5.23^{\mathrm{dA}}$ \\
\hline $\mathrm{T} 1$ & $0.19^{\mathrm{C}}$ & $0.22^{\mathrm{C}}$ & $0.91^{\mathrm{C}}$ & $1.45^{\mathrm{bC}}$ & $1.46^{\mathrm{bC}}$ & $2.19^{\mathrm{bB}}$ & $2.48^{\mathrm{bB}}$ & $3.22^{\mathrm{bB}}$ & $4.39^{\mathrm{cA}}$ & $7.08^{\mathrm{Ca}}$ \\
\hline $\mathrm{T} 2$ & $0.25^{\mathrm{D}}$ & $0.24^{\mathrm{D}}$ & $1.28^{\mathrm{D}}$ & $1.60^{\mathrm{bD}}$ & $1.68^{\mathrm{bD}}$ & $3.58^{\mathrm{aC}}$ & $2.72^{\mathrm{bC}}$ & $5.72^{\mathrm{aB}}$ & $8.63^{\mathrm{bB}}$ & $17.67^{\mathrm{bA}}$ \\
\hline $\mathrm{T} 3$ & $0.28^{\mathrm{C}}$ & $0.26^{\mathrm{C}}$ & $1.35^{\mathrm{C}}$ & $2.49^{\mathrm{aC}}$ & $2.07^{\mathrm{aC}}$ & $3.03^{\mathrm{aC}}$ & $3.24^{\mathrm{aC}}$ & $4.33^{\mathrm{aC}}$ & $13.29^{\mathrm{aB}}$ & $20.14^{\mathrm{aA}}$ \\
\hline \multicolumn{11}{|l|}{ VBN } \\
\hline $\mathrm{C}$ & $2.32^{\mathrm{bC}}$ & $4.75^{\mathrm{bC}}$ & $4.87^{\mathrm{bC}}$ & $7.12^{\mathrm{bB}}$ & $8.02^{\mathrm{bB}}$ & $8.11^{\mathrm{bB}}$ & $12.45^{\mathrm{bA}}$ & $17.72^{\mathrm{cA}}$ & $19.13^{\mathrm{bA}}$ & $16.11^{\mathrm{bA}}$ \\
\hline $\mathrm{T} 1$ & $2.46^{\mathrm{bD}}$ & $6.91^{\mathrm{aC}}$ & $8.94^{\mathrm{aC}}$ & $7.13^{\mathrm{bC}}$ & $10.27^{\mathrm{aB}}$ & $9.80^{\mathrm{bB}}$ & $13.85^{\mathrm{bB}}$ & $21.93^{\mathrm{bA}}$ & $20.45^{\mathrm{bA}}$ & $27.33^{\mathrm{aA}}$ \\
\hline $\mathrm{T} 2$ & $4.96^{\mathrm{aC}}$ & $7.42^{\mathrm{aC}}$ & $8.85^{\mathrm{aC}}$ & $10.21^{\mathrm{aB}}$ & $12.12^{\mathrm{aB}}$ & $14.13^{\mathrm{aB}}$ & $18.88^{\mathrm{aB}}$ & $27.12^{\mathrm{aA}}$ & $28.30^{\mathrm{aA}}$ & $28.11^{\mathrm{aA}}$ \\
\hline $\mathrm{T} 3$ & $4.98^{\mathrm{aC}}$ & $8.89^{\mathrm{aB}}$ & $9.61^{\mathrm{aB}}$ & $10.20^{\mathrm{aB}}$ & $11.61^{\mathrm{aB}}$ & $11.90^{\mathrm{aB}}$ & $15.11^{\mathrm{aB}}$ & $26.27^{\mathrm{aA}}$ & $26.06^{\mathrm{aA}}$ & $28.71^{\mathrm{aA}}$ \\
\hline \multicolumn{11}{|c|}{ TBA (mg malonaldehyde/kg) } \\
\hline $\mathrm{C}$ & $0.38^{\mathrm{B}}$ & $0.52^{\mathrm{B}}$ & $1.00^{\mathrm{aA}}$ & $1.44^{\mathrm{aA}}$ & $1.49^{\mathrm{aA}}$ & $1.52^{\mathrm{aA}}$ & $1.50^{\mathrm{aA}}$ & $1.62^{\mathrm{aA}}$ & $1.68^{\mathrm{aA}}$ & $1.57^{\mathrm{aA}}$ \\
\hline $\mathrm{T} 1$ & $0.36^{\mathrm{B}}$ & $0.53^{\mathrm{B}}$ & $0.80^{\mathrm{aA}}$ & $1.30^{\mathrm{aA}}$ & $1.30^{\mathrm{aA}}$ & $1.13^{\mathrm{aA}}$ & $1.14^{\mathrm{aA}}$ & $1.26^{\mathrm{aA}}$ & $1.35^{\mathrm{aA}}$ & $1.10^{\mathrm{aA}}$ \\
\hline $\mathrm{T} 2$ & 0.39 & 0.48 & $0.59^{\mathrm{b}}$ & $0.61^{\mathrm{b}}$ & $0.73^{\mathrm{b}}$ & $0.73^{\mathrm{b}}$ & $0.57^{\mathrm{b}}$ & $0.78^{\mathrm{b}}$ & $0.84^{\mathrm{b}}$ & $0.74^{\mathrm{b}}$ \\
\hline $\mathrm{T} 3$ & 0.40 & 0.48 & $0.60^{\mathrm{b}}$ & $0.59^{\mathrm{b}}$ & $0.62^{\mathrm{b}}$ & $0.63^{\mathrm{b}}$ & $0.37^{\mathrm{b}}$ & $0.70^{\mathrm{b}}$ & $0.77^{\mathrm{b}}$ & $0.77^{\mathrm{b}}$ \\
\hline
\end{tabular}

VBN, volatile basic nitrogen; TBA, thiobarbituric acid.

Values are presented as means \pm standard deviation of three replicate experiments with three samples analyzed per replicate $(n=9)$.

${ }^{1}$ C, 30\% fat; T1, 20\% fat; T2, 10\% fat; T3, 5\% fat.

${ }^{\mathrm{a}-\mathrm{d}}$ Figures with different letters within a same column differ significantly $(\mathrm{p}<0.05)$.

${ }^{A-F}$ Figures with different letters within a same row differ significantly $(p<0.05)$. 
contamination (Lee and Joo, 1999). During ripening and drying, fermented sausages with low-fat had significantly higher VBN than those with high-fat $(\mathrm{p}<0.05)$ (Table 2$)$. The high content of VBN in low fat sausage seems due to the higher content of protein in low fat sausage. According to the studies of Egan et al. (1981), the higher VBN of sausages with low-fat is explained by accelerated protein degradation. The VBN value of sausages continuously increased during the ripening period $(\mathrm{p}<0.05)$. However, it remained up to $21 \mathrm{st}$ day at values less than $30 \mathrm{mg} / \%$. The range in VBN values is 7 to $18 \mathrm{mg}(\mathrm{VBN} / 100 \mathrm{~g})$ in Chinese style dry-cured sausages during the ripening period (Lin and Lin, 2002). As presented in Table 2, the lipid oxidation of sausages steadily increased during fermentation and ripening $(p<0.05)$. The casings used for stuffing are permeable to air. Therefore, fermented sausages are exposed to oxygen and, in consequence, to increase lipid oxidation (Liaros et al., 2009). After 7 days of storage, the TBA values of fermented sausages were higher in high-fat (C and $\mathrm{T} 1$ ) compared to low-fat (T2 and $\mathrm{T} 3$ ) sausages $(p<0.05)$. This could be explained by differences in lipid stability as the result of higher fat content. Low-fat fermented sausages had TBA values lower than $1 \mathrm{mg}$ malonaldehyde $/ \mathrm{kg}$, which is considered the limit of acceptability for rancidity for fresh meat (Ockerman, 1976).

The influence of fat level for pork backfat on color of fermented sausages is shown in Table 3 . No differences in $\mathrm{L}^{*}$ and $\mathrm{b}^{*}$ were found between treatments during ripening and drying. However, lower fat levels produced redder sausages $(p<0.05)$. These results are in agreement with those reported by many authors (Soyer et al., 2005; Liaros et al., 2009) mentioned low-fat fermented sausages were redder than higher fat sausages. This difference is due to the higher lean beef and pork contents used for the production of the meat mixture for low-fat sausages, and consequently to their higher myoglobin content. The $\mathrm{a}^{*}$ values increased very rapidly during the first 5 days in sausages and decreased slowly after 7 days of storage $(p<0.05)$. This increase in redness is attributed to the formation of nitrosylmyoglobin (Papadima and Bloukas, 1999). The small decrease in $a^{*}$ values of sausages may be due to the oxidation of nitrosylmyoglobin to nitrate and the brown metmyoglobin (Gøtterup et al., 2008). The L* values decreased slightly during the ripening period, but was not statistically significant $(p>0.05)$. However, the $b^{*}$ values decreased slightly during the ripening period $(p<0.05)$. This result was similar to that of the yellowness of Spanish sausage, which decreases during the ripening period (PérezAlvarez et al., 1999).

The influence of fat level for pork backfat on bacteria count of fermented sausages is shown in Table 4. The initial count of total plate bacteria and Pseudomonas counts in the sausage mixture was about $10^{6} \log \mathrm{CFU} / \mathrm{g}$ and remained unchanged up to the 21 st day. This attribute is due to a lack of fermentable carbohydrates (Papadima and Bloukas, 1999). Total plate bacteria and Pseudomonas counts of sausages were not significantly affected by fat level $(\mathrm{p}>0.05)$. Previous studies have shown that fat level had no effect on lactic acid bacteria counts (Muguerza et al., 2002; Liaros et al., 2009). Bacteria counts of sausages appeared to

Table 3. Effect of fat level for pork backfat on meat color of fermented sausages

\begin{tabular}{|c|c|c|c|c|c|c|c|c|c|c|}
\hline \multirow{2}{*}{ Variable } & \multicolumn{10}{|c|}{ Days of ripening } \\
\hline & 0 & 1 & 2 & 3 & 4 & 5 & 7 & 10 & 14 & 21 \\
\hline \multicolumn{11}{|l|}{$\overline{\mathrm{L}^{*}}$} \\
\hline $\mathrm{C}^{1}$ & 52.96 & 51.30 & 51.98 & 53.21 & 53.62 & 51.07 & 49.02 & 48.28 & 48.65 & 49.10 \\
\hline $\mathrm{T} 1$ & 52.19 & 50.49 & 51.07 & 51.99 & 53.50 & 52.04 & 50.22 & 48.46 & 47.81 & 46.87 \\
\hline $\mathrm{T} 2$ & 50.74 & 48.45 & 49.85 & 50.35 & 53.21 & 49.67 & 49.65 & 45.90 & 46.97 & 46.40 \\
\hline $\mathrm{T} 3$ & 47.10 & 46.35 & 47.75 & 48.64 & 50.54 & 49.00 & 49.39 & 49.39 & 46.56 & 46.49 \\
\hline \multicolumn{11}{|l|}{$a^{*}$} \\
\hline $\mathrm{C}$ & $3.79^{\mathrm{b}}$ & $2.32^{\mathrm{b}}$ & $4.08^{\mathrm{b}}$ & $5.56^{\mathrm{b}}$ & $6.75^{\mathrm{c}}$ & $6.35^{\mathrm{c}}$ & $4.54^{\mathrm{b}}$ & $4.97^{\mathrm{b}}$ & $3.66^{\mathrm{b}}$ & $3.47^{\mathrm{b}}$ \\
\hline $\mathrm{T} 1$ & $3.54^{\mathrm{b}}$ & $2.42^{\mathrm{b}}$ & $4.10^{\mathrm{b}}$ & $5.86^{\mathrm{b}}$ & $7.73^{b}$ & $8.78^{b}$ & $7.15^{\mathrm{a}}$ & $5.62^{\mathrm{b}}$ & $4.46^{\mathrm{b}}$ & $4.22^{\mathrm{b}}$ \\
\hline $\mathrm{T} 2$ & $5.44^{\mathrm{a}}$ & $5.98^{\mathrm{a}}$ & $6.92^{\mathrm{a}}$ & $8.35^{\mathrm{a}}$ & $9.31^{\mathrm{a}}$ & $9.88^{\mathrm{a}}$ & $8.78^{\mathrm{a}}$ & $6.90^{\mathrm{a}}$ & $6.61^{\mathrm{a}}$ & $6.98^{\mathrm{a}}$ \\
\hline $\mathrm{T} 3$ & $5.55^{\mathrm{a}}$ & $5.78^{\mathrm{a}}$ & $6.44^{\mathrm{a}}$ & $9.26^{\mathrm{a}}$ & $10.30^{\mathrm{a}}$ & $10.08^{\mathrm{a}}$ & $8.63^{\mathrm{a}}$ & $8.63^{\mathrm{a}}$ & $5.79^{\mathrm{a}}$ & $6.10^{\mathrm{a}}$ \\
\hline \multicolumn{11}{|l|}{$b^{*}$} \\
\hline $\mathrm{C}$ & $6.30^{\mathrm{A}}$ & $4.83^{\mathrm{A}}$ & $4.22^{\mathrm{A}}$ & $4.95^{\mathrm{A}}$ & $4.52^{\mathrm{A}}$ & $3.57^{\mathrm{B}}$ & $3.19^{\mathrm{B}}$ & $3.54^{\mathrm{B}}$ & $2.51^{\mathrm{C}}$ & $2.40^{\mathrm{C}}$ \\
\hline $\mathrm{T} 1$ & $5.27^{\mathrm{A}}$ & $4.58^{\mathrm{A}}$ & $4.50^{\mathrm{A}}$ & $4.47^{\mathrm{A}}$ & $5.41^{\mathrm{A}}$ & $5.36^{\mathrm{A}}$ & $4.39^{\mathrm{A}}$ & $3.22^{\mathrm{B}}$ & $2.44^{\mathrm{C}}$ & $2.38^{\mathrm{C}}$ \\
\hline $\mathrm{T} 2$ & $5.91^{\mathrm{A}}$ & $4.07^{\mathrm{A}}$ & $4.16^{\mathrm{A}}$ & $4.11^{\mathrm{A}}$ & $5.51^{\mathrm{A}}$ & $5.06^{\mathrm{A}}$ & $4.37^{\mathrm{A}}$ & $3.00^{\mathrm{B}}$ & $3.08^{\mathrm{B}}$ & $3.29^{\mathrm{B}}$ \\
\hline $\mathrm{T} 3$ & $4.04^{\mathrm{A}}$ & $3.95^{\mathrm{A}}$ & $3.92^{\mathrm{A}}$ & $4.08^{\mathrm{A}}$ & $4.76^{\mathrm{A}}$ & $5.11^{\mathrm{A}}$ & $4.32^{\mathrm{A}}$ & $4.32^{\mathrm{A}}$ & $3.45^{\mathrm{B}}$ & $2.58^{\mathrm{B}}$ \\
\hline
\end{tabular}

L, lightness; a, redness; b, yellowness.

Values are presented as means \pm standard deviation of three replicate experiments with three samples analyzed per replicate $(n=9)$.

${ }^{1}$ C, $30 \%$ fat; T1, 20\% fat; T2, 10\% fat; T3, 5\% fat.

${ }^{\mathrm{a}-\mathrm{c}}$ Figures with different letters within a same column differ significantly $(\mathrm{p}<0.05)$.

${ }^{A-C}$ Figures with different letters within a same row differ significantly $(\mathrm{p}<0.05)$. 
Table 4. Effect of fat level for pork backfat on total plate counts and Pseudomonas of fermented sausages

\begin{tabular}{|c|c|c|c|c|c|c|c|c|c|c|}
\hline \multirow{2}{*}{ Variable } & \multicolumn{10}{|c|}{ Days of ripening } \\
\hline & 0 & 1 & 2 & 3 & 4 & 5 & 7 & 10 & 14 & 21 \\
\hline \multicolumn{11}{|c|}{ Total plate counts (log CFU/g) } \\
\hline $\mathrm{C}^{1}$ & 6.74 & 6.84 & 6.31 & 6.03 & 6.13 & 5.94 & 6.45 & 6.25 & 6.25 & 6.04 \\
\hline $\mathrm{T} 1$ & 6.68 & 6.80 & 6.24 & 5.92 & 5.96 & 5.81 & 6.31 & 6.41 & 6.31 & 6.48 \\
\hline $\mathrm{T} 2$ & 6.61 & 6.90 & 6.21 & 6.01 & 5.96 & 6.01 & 6.11 & 6.43 & 6.41 & 6.01 \\
\hline $\mathrm{T} 3$ & 6.79 & 6.85 & 6.44 & 6.08 & 5.96 & 6.01 & 6.34 & 6.45 & 6.42 & 6.07 \\
\hline \multicolumn{11}{|c|}{ Pseudomonas (log CFU/g) } \\
\hline $\mathrm{C}$ & 6.71 & 6.66 & 6.23 & 5.70 & 5.77 & 5.63 & 6.21 & 5.95 & 6.07 & 5.95 \\
\hline $\mathrm{T} 1$ & 6.61 & 6.65 & 6.00 & 5.82 & 5.89 & 5.64 & 6.10 & 6.04 & 6.30 & 6.35 \\
\hline $\mathrm{T} 2$ & 6.51 & 6.70 & 6.21 & 5.74 & 5.56 & 5.69 & 5.80 & 6.24 & 6.23 & 6.23 \\
\hline $\mathrm{T} 3$ & 6.71 & 6.82 & 6.60 & 6.19 & 5.74 & 5.92 & 6.30 & 6.22 & 6.32 & 6.26 \\
\hline
\end{tabular}

CFU, colony-forming unit.

Values are presented as means \pm standard deviation of three replicate experiments with three samples analyzed per replicate $(\mathrm{n}=9)$.

${ }^{1}$ C, $30 \%$ fat; T1, 20\% fat; T2, 10\% fat; T3, 5\% fat.

be not related to higher fat content in this study.

\section{CONCLUSION}

This result showed that the fat level for pork backfat significantly affects the proximate composition and physicochemical characteristics of fermented sausages during ripening and drying. This was also able to produce low fat fermented sausages without negative effects on the bacteria counts, except for only a higher VBN and weight loss. Further research is needed to improve the sensory attributes of these products, particularly their fatty acid. The result of this study could provide useful information to produce healthier reduced fat fermented sausages.

\section{CONFLICT OF INTEREST}

We certify that there is no conflict of interest with any financial organization regarding the material discussed in the manuscript.

\section{ACKNOWLEDGMENTS}

This research was supported by research funds of Sangji University.

\section{REFERENCES}

Barbut, S. and G. S. Mittal. 1996. Effects of three cellulose gums on the texture profile and sensory properties of low fat frankfurters. Int. J. Food. Sci. Technol. 31:241-247.

Bloukas, J. G., E. D. Paneras, and G. C. Fournitzis. 1997. Effect of replacing pork backfat with olive oil on processing and quality characteristics of fermented sausages. Meat Sci. 45:133-144.

Bourne, M. C. 1978. Texture profile analysis. Food. Technol.
$32: 72$.

Conway, E. J. 1950. Microdiffusion Analysis and Volumetric Error. 3rd edn. Crosby Lockwood and Son Ltd., London, UK.

Egan, H., R. S. Kirk, R. Sawyer, and D. Pearson. 1981. Pearson's Chemical Analysis of Foods. 8th edn. Longman scientific and Technical, Essex, UK.

Gøtterup, J., K. Olsen, S. Knøchel, K. Tjener, L. H. Stahnke, and J. K. Møller. 2008. Colour formation in fermented sausages by meat-associated staphylococci with different nitrite- and nitrate-reductase activities. Meat Sci. 78:492-501.

Giese, J. 1996. Fats, oils and fat replacers. Food. Technol. 50:7883.

Horwitz, W. 2000. Official Methods of Analysis of AOAC International. 17th edn. AOAC International, Gaithersburg, MD, USA.

Kris-Etherton, P. M., D. Krummel, M. E. Russell, D. Dreon, S. Mackey, J. Borchers, and P. D. Wood. 1988. The effect of diet on plasma lipids, lipoproteins, and coronary heart disease. J. Am. Diet. Assoc. 88:1373-1400.

Lee, J. G. and S. T. Joo. 1999. Effects of slaughter weight on backfat thickness, intramuscular fat and physical properties of pork loin from barrow. Korean J. Anim. Sci. 41:207-214.

Liaros, N. G., E. Katsanidis, and J. G. Bloukas. 2009. Effect of the ripening time under vacuum and packaging film permeability on processing and quality characteristics of low-fat fermented sausages. Meat Sci. 83:589-598.

Lin, K. W. and S. N. Lin. 2002. Effects of sodium lactate and trisodium phosphate on the physicochemical properties and shelf life of low-fat Chinese-style sausage. Meat Sci. 60:147154.

Mendoza, E., M. L. García, C. Casas, and M. D. Selgas. 2001. Inulin as fat substitute in low fat, dry fermented sausages. Meat Sci. 57:387-393.

Muguerza, E., G. Fista, D. Ansorena, I. Astiasaran, and J. G. Bloukas. 2002. Effect of fat level and partial replacement of pork backfat with olive oil on processing and quality characteristics of fermented sausages. Meat Sci. 61:397-404. 
guidelines for healthy American adults. A statement for physicians and health professionals by the Nutrition Committee, American Heart Association. Circulation. 74:1465A-1468A.

Ockerman, H. W. 1976. Quality Control of Post-mortem Muscle and Tissue. Department of Animal Science, Ohio State University, Columbus, OH, USA.

Olivares, A., J. L. Navarro, A. Salvador, and M. Flores. 2010. Sensory acceptability of slow fermented sausages based on fat content and ripening time. Meat Sci. 86:251-257.

Pérez-Alvarez, J. A., M. E. Sayas-Barberá, J. Fernández-López, and V. Aranda-Catalá. 1999. Physicochemical characteristics of Spanish-type dry-cured sausage. Food. Res. Int. 32:599-607.

Papadima, S. N. and J. G. Bloukas. 1999. Effect of fat level and storage conditions on quality characteristics of traditional Greek sausages. Meat Sci. 51:103-113.
Quarantine and Inspection Agency. 2014. Standards for Processing and Ingredients Specifications of Livestock Products, Animal, Plant and Fisheries Quarantine and Inspection Agency Notification (No. 2012-118). Animal, Plant and Fisheries Quarantine and Inspection Agency, Anyang, Korea.

SAS. 2002. SAS/STAT Software for PC. Release 6.11. SAS Institute, Cary, NC, USA.

Soyer, A., A. H. Ertaş, and U. Uzümcüog`lu. 2005. Effect of processing conditions on the quality of naturally fermented Turkish sausages (sucuks). Meat Sci. 69:135-141.

Wirth, F. 1988. Technologies for making fat-reduce meat products. What possibilities are there? Fleischwirtsch 68:1153-1156.

Witte, V. C., G. F. Krause, and M. E. Bailey. 1970. A new extraction method for determining 2-thiobarbituric acid values of pork. Food. Technol. 8:326.

World Health Organization. 2003. Diet, nutrition and the prevention of chronic diseases. WHO Technical Report Series, 916, (Geneva). 